\title{
Occurrence of abortions induced by Neospora caninum in dairy cattle from Santa Catarina, southern Brazil
}

\author{
Ocorrência de abortamentos induzidos por Neospora caninum em vacas de leite de Santa Catarina, \\ sul do Brasil \\ Cesar Augusto Barbosa de Macedo ${ }^{1}$; Madlaine Frigo Silveira Barbosa de Macedo ${ }^{1}$; Ana Carolina Miura ${ }^{2}$; \\ Alessandra Taroda ${ }^{2}$; Sergio Tosi Cardim²; Elisabeth Ann Innes ${ }^{3}$; Frank Katzer ${ }^{3}$; German Jose Cantón ${ }^{3,4}$; \\ Francesca Chianini³; Selwyn Arlington Headley²; João Luis Garcia²* \\ ${ }^{1}$ Companhia Integrada de Desenvolvimento Agrícola de Santa Catarina - CIDASC, Presidente Getúlio, SC, Brasil \\ ${ }^{2}$ Departamento de Medicina Veterinária Preventiva, Universidade Estadual de Londrina - UEL, Londrina, PR, Brasil \\ ${ }^{3}$ Moredun Research Institute, Pentlands Science Park, Bush Loan, Penicuik, EH26 0PZ, United Kingdom \\ ${ }^{4}$ Instituto Nacional de Tecnología Agropecuaria - INTA, Estación Experimental de Balcarce - EEA, CC276, Argentina
}

Received January 29, 2017

Accepted August 21, 2017

\begin{abstract}
The aim of the present study was to investigate the occurrence of $N$. caninum associated with abortions of dairy cattle from Santa Catarina state, southern Brazil by using enzyme-linked immunosorbent assay (ELISA), immunohistochemistry (IHC), and polymerase chain reaction (PCR). Blood from dairy cows that aborted along with intrathoracic fluid and tissue samples (brain, heart, liver, and lung) from their fetuses were collected and used for serology; PCR, histopathological, and immunohistochemistry (IHC) evaluations were also conducted. Twenty-one cows (51.2\%) out of 41, and eight fetuses $(26.7 \%)$ out of 30 were ELISA (HerdCheck, IDEXX) positive for $N$. caninum. Dams > 36 months of age had a higher risk of being serum positive than younger animals. PCR and IHC revealed that 38.8\% (14/36) and 25.0\% (9/36) of the fetuses were positive for $N$. caninum, respectively for each of the tests. Seropositive cows had a higher frequency of fetuses that were also positive by either intrathoracic fluid, PCR, or IHC. In summary, the present study observed a high frequency of $N$. caninum in abortions from dairy cows from southern Brazil, with a higher $N$. caninum prevalence found in cows that were older than 36 months. In addition, serology, PCR, and IHC should be used all together for better diagnosis of neosporosis in cattle.
\end{abstract}

Keywords: Neosporosis, fetuses, lesion, serology, cattle.

\section{Resumo}

O objetivo deste estudo foi avaliar a ocorrência de $N$. caninum associado a abortamentos em vacas de leite do estado de Santa Catarina, sul do Brasil pelo uso das técnicas de ELISA (HerdCheck, IDEXX), reação em cadeia pela polimerase (PCR) e imunohistoquímica (IHC). O sangue das vacas leiteiras que abortaram, bem como, o líquido intratorácico e amostras de tecidos (cérebro, coração, fígado e pulmão) de seus fetos foram coletados e usados para sorologia, PCR (Np21+ e Np6+), e IHC. Vinte e uma vacas $(51,2 \%)$ de um total de 41, bem como, oito fetos $(26,7 \%)$ de um total de 30 foram positivos no ELISA (IDEXX) para N. caninum. As vacas > 36 meses de idade tiveram um maior risco de serem soropositivas do que os animais mais jovens. PCR e IHC revelaram que 38,8\% e 25,0\% dos fetos foram positivos para $N$. caninum, respectivamente para cada um dos testes. As vacas soropositivas tiveram uma maior frequência de fetos que também foram positivos no fluído intratorácico, na PCR ou na IHC. Em resumo, o presente estudo observou uma alta frequência de $N$. caninum em abortos de vacas leiteiras na regiáo estudada, com maior prevalência de $N$. caninum em vacas com mais de 36 meses de idade. Além disso, sorologia, PCR e IHC deveriam ser utilizadas conjuntamente para melhor diagnóstico de neosporose em bovinos.

Palavras-chaves: Neosporose, bovinos, sorologia, vacas, diagnóstico.

\footnotetext{
*Corresponding author: João Luis Garcia. Universidade Estadual de Londrina

- UEL, Rodovia Celso Garcia Cid, s/n, Campus Universitário, Km 380, CP 6001,

CEP 86057-970, Londrina, PR, Brasil. e-mail: joaoluisgarcia10@gmail.com
} 


\section{Introduction}

Neospora caninum is a protozoan parasite of animals that may have been misdiagnosed as Toxoplasma gondii until 1988 when it was recognized as a distinct Species (DUBEY et al., 2007, 2011). Dogs (Canis lupus familiaris), coyotes (Canis latrans), dingoes (Canis lupus dingo), and gray wolfs (C. lupus) are considered as definitive hosts for this parasite (DUBEY et al., 2011; GONDIM et al., 2004; KING et al., 2010; McALLISTER et al., 1998). Additionally, several livestock and wild animal species have been identified as intermediate hosts of $N$. caninum (DUBEY \& LINDSAY, 1996). Moreover, surveys conducted in several countries have identified $N$. caninum infections as the major cause of bovine abortions (ANDERSON et al., 2000), particularly among dairy cattle (DUBEY \& LINDSAY, 1996).

$N$. caninum can be either transmitted postnatally (horizontal) by the ingestion of food and/or drinking water contaminated with sporulated oocysts, or transplacentally (vertical) (DUBEY, 2005; DUBEY et al., 2007). Vertical transmission of $N$. caninum from one generation to the next generation of cattle appears to be the major route by which the infection is maintained within herds (BILDFELL et al., 1994; HALL et al., 2005; WOUDA, 2000). Vertical transmission may result in fetuses that may die in utero, be reabsorbed, mummified, autolyzed, stillborn, born alive with clinical signs, or born clinically normal but persistently infected (DUBEY, 2003; HADDAD et al., 2005).

The diagnosis of $N$. caninum-induced abortions is often expensive and sometimes difficult, either because of the absence of fetus and placenta, especially for beef cattle, or the use of just serology, what may be inconclusive. Serological examination of the dam and fetus (DUBEY \& LINDSAY, 1996), observation of histopathological lesions, immunohistochemistry (ANDERSON et al., 2000), and parasite detection by PCR techniques (COLLANTES-FERNANDEZ et al., 2006) are tools that may contribute to a successful diagnosis of bovine Neospora abortion.

In Brazil, $N$. caninum was considered an important abortifacient agent in cattle (CORBELLINI et al., 2002; SANTOS et al., 2005b; CORBELLINI et al., 2006; ORLANDO et al., 2013; PESCADOR et al., 2007; CABRAL et al., 2009). Corbellini et al. (2002) showed in Rio Grande do Sul state, southern Brazil, 81\% of the aborted fetuses with brain lesions suggestive of $N$. caninum. Santos et al. (2005b) showed by immunohistochemistry this parasite in eight out of 30 fetuses coming from 22 dairy herds from Paraná state, those fetuses were between 3 to 7 months of age. Additionally, in Sao Paulo state, $24.8 \%$ of fetuses were found infected with N. caninum (CABRAL et al., 2009).

Those previous studies, characterized $N$. caninum by either histopathology or immunohistochemistry (IHC) of aborted fetuses. Thus, the aim of the present study was to investigate the occurrence of $N$. caninum associated with abortions of dairy cattle from Santa Catarina state, southern Brazil by using enzyme-linked immunosorbent assay (ELISA), immunohistochemistry (IHC), and polymerase chain reaction (PCR).

\section{Material and Methods}

\section{Study area and sampling}

The survey was done in the city of Presidente Getulio ( $\left.27^{\circ} 03^{\prime} 03^{\prime \prime} \mathrm{S}, 49^{\circ} 37^{\prime} 22^{\prime \prime} \mathrm{N}\right)$, located at an altitude of $255 \mathrm{~m}$ in the Itajaí river valley of the state of Santa Catarina, southern Brazil. Forty-one dairy cows (Bos taurus) from Holstein and Jersey breed and their aborted fetuses derived from thirty-five dairy farms, were analyzed. At first sampling blood of cows and tissues and fluids of aborted fetuses were collected. Further, all farms were revisited to obtain a second blood sample from the cows 30 days after abortion. This project was approved by Animal Ethical Committee from Universidade Estadual de Londrina (number 18/09).

\section{Blood, intrathoracic fluid and tissue samples}

Blood samples, with and without EDTA, were collected from the dairy cows that aborted, while intrathoracic fluid was obtained from their fetuses. The white blood cells (WBC) were separated by centrifugation $(550 \mathrm{xg}-10 \mathrm{~min})$, and used for DNA extraction and in PCR assays. Additionally, a pool of tissue fragments (brain, heart, liver, and lung) from each fetus was obtained and used in PCR assays. All tissue samples were homogenized in $10 \mathrm{ml}$ of saline solution $(0.14 \mathrm{M} \mathrm{NaCl})$, the homogenate filtered through two layers of gauze, after which $2 \mathrm{ml}$ were used for DNA extraction.

\section{Anti-Neospora caninum antibody detection}

Antibodies against $N$. caninum were detected using a commercial indirect ELISA test (HerdCheck, IDEXX) that used N. caninum tachyzoite-soluble proteins as the antigen. Sera from cows and fluid from fetuses were diluted 1:100 and 1:25 (WOUDA et al., 1997), respectively. The presence or absence of antibodies to $N$. caninum was determined by calculating the ratio of the result for the sample to the result for the positive control $(\mathrm{S} / \mathrm{P})$ for each sample. The ratio $(\mathrm{S} / \mathrm{P})$ was calculated as follows: (sample optical density - mean negative control)/(mean positive control - mean negative control). Serum samples with a ratio $(\mathrm{S} / \mathrm{P})<0.50$ were classified as negative and ratio $(\mathrm{S} / \mathrm{P}) \geq 0.50$ as positive. The sensitivity (Se) and specificity (Sp) of the test were $99 \%$ and $97.5 \%$, respectively (VON BLUMRODER et al., 2004). A cow with a single or two positive ELISA results was considered as $N$. caninum infected.

\section{DNA extraction and PCR}

DNA extractions from WBC, and intrathoracic fluid, and tissues were performed by using the PureLink ${ }^{\mathrm{TM}}$ Genomic DNA Purification kit (Invitrogen) following the manufacture's recommendations, and a negative control (water) was included in each DNA extraction. All PCR assays were done as previously described (MARQUES et al., 2011). N. caninum DNA was amplified by using the Np21+ and Np6+ primers (MULLER et al., 2001) in a PCR assay performed in a mixture containing $5 \mu$ l of extracted DNA with $20 \mu \mathrm{l}$ (final volume of $25 \mu \mathrm{l}$ ) of mixture of $1.0 \mathrm{mM}$ of 
each primer, $100 \mathrm{mM}$ dNTP (Invitrogen, Life Technologies. USA), 60mM Tris- $\mathrm{HCl}$ (pH 9.0), 15mM (NH4)2SO4, $1.5 \mathrm{mM} \mathrm{MgCl}_{2}$ and 0.5U Taq DNA polymerase (Invitrogen, Life Technologies. USA). Amplification of protozoan DNA was done over 35 cycles in a PTC-100 thermocycler (MJ-Research), using the following cycling conditions for PCR: 5 min at $94^{\circ} \mathrm{C}$, followed by 35 cycles for $30 \mathrm{~s}$ at $94^{\circ} \mathrm{C}, 30 \mathrm{~s}$ at $65^{\circ} \mathrm{C}$ and $60 \mathrm{~s}$ at $72{ }^{\circ} \mathrm{C}$. Cycle 35 was followed by a final extension of $7 \mathrm{~min}$ at $72^{\circ} \mathrm{C}$. Aliquots of each PCR product were electrophoresed on $2 \%$ agarose gels. Tachyzoites of the NC-1 strain $\left(10^{6} / \mathrm{ml}\right)$ were diluted in TE buffer, the DNA extracted, and used as positive control. The negative control consisted of water samples without $N$. caninum; positive and negative controls were included in each assay.

\section{Pathological evaluation}

Cerebrum tissue fragments were collected from all fetuses, and fixed by immersion in $10 \%$ buffered formalin solution, routinely processed for histopathological evaluation, and then evaluated for the presence of pathological alterations.

\section{Immunohistochemistry}

Cerebrum, myocardium, lung and liver tissue fragments from fetuses were placed into $10 \%$ formal saline solution and fixed for five days. The fixed tissues were then processed by standard procedures to paraffin-wax blocks, after which slides were produced for hematoxylin and eosin staining (MALEY et al., 2003). The immunohistochemistry technique was done as previously described (MALEY et al., 2003). Briefly, paraffin-wax sections were cut and mounted on polylysinated glass slides (Superfrost ${ }^{\circledR}$ Plus; Menzel-Gläser) and dried overnight at $37^{\circ} \mathrm{C}$. Glass slides were dewaxed and rehydrated. Endogenous peroxidase was blocked by incubating with $4 \%$ hydrogen peroxide in methanol for $30 \mathrm{~min}$ at room temperature (RT). Non-specific labeling was reduced by incubation with $25 \%$ normal goat serum in TBS for $30 \mathrm{~min}$ at RT. The tissue sections were then incubated overnight at $4{ }^{\circ} \mathrm{C}$ with polyclonal primary antibodies produced against $N$. caninum tachyzoites (VMRD Inc, Washington, USA). After washes with TBS, anti-rabbit IgG polymers (Dako EnVision ${ }^{\circledR}$ ) were employed as secondary antibodies. The reaction was revealed after incubation with DAB chromogen (Dako EnVision ${ }^{\circledR}$ ) for 8 min. Slides were then washed with distilled water and counterstained using Mayer's Hematoxylin for 30 seconds before being dehydrated and mounted.

\section{Statistical analysis}

Variables were analyzed by the Chi-square test $\left(\chi^{2}\right)$ corrected by the Yates, Fisher Exact Test using the Epi 6 program (CDC. 6.04b version). The association among variables and occurrence of seropositivity was estimated from values obtained by the odds ratio (OR) with a confidence interval of $95 \%$. A $p$-value of $\leq 0.05$ was considered as significant in both tests.

\section{Results}

The results for $N$. caninum from cows and aborted fetuses are shown in Table 1. From the 41 dairy cows that aborted 21 (51.2\%) were seropositive for $N$. caninum. The average $S / P$ value of cows by ELISA, in the first bleeding, was $1.12 \pm 0.98$. The average gestational age of abortions was $6.77 \pm 1.16$ months; $13(34.2 \%)$ were aborted at 4-6 months of pregnancy and $25(65.8 \%)$ at 7-9 months. At second revisited six animals were slaughtered and consequently could not be sampled, thus, 35 paired serum samples were obtained. The positivity at the second collection was $48.5 \%(17 / 35)$ with an $S / P$ average $=1.01 \pm 0.91$. The sample of one cow (N.10) was seropositive during the first reaction but negative at the second round of sampling, and thus considered as $N$. caninum infected. No blood samples derived from cows were positive by PCR.

Three fetuses were mummified, preventing ELISA or PCR evaluations. Eight (26.7\%) out of 30 fetal intrathoracic fluids were positive by ELISA, the average of fetal gestational age was $7.22 \pm 0.66$ months, and the average of S/P for fetuses was $S / P=0.56 \pm 1.04$; six $(35.3 \%)$ and four $(23.5 \%)$ of these animals were positive by PCR and IHC, respectively (Table 1). A total of $14(38.8 \%)$ and $9(25 \%)$ tissue samples from 36 fetuses were positive by PCR and by IHC, respectively.

The most significant histopathological alterations observed are shown in Table 1 . These consisted primarily of vascular alterations, and included hypertrophy of endothelial cells and congestion of blood vessels; intralesional cysts were not observed. The IHC test detected $N$. caninum antigens in four heart and six brain samples. There were no IHC positive results either in lung or liver.

Cows between 24-36 months of age had a protector factor of being serum positive [OR=0.00; $(0.00<\mathrm{OR}<0.31) ; \mathrm{p}=0.0001]$ than animals $>36$ months of age (Table 2). All cows aborted at more than four months of gestation, and there were no statistical differences $(p=0.84)$. No significant differences $(p=0.97)$ were observed when the breed (Holstein and Jersey) of the cows was evaluated.

When we compared the positive maternal ELISA results with the results obtained by ELISA, PCR, and IHC from their fetuses we observed higher frequencies of having either serum $(\mathrm{p}=0.0002)$, PCR $(\mathrm{OR}=9.78 ; 1.63<\mathrm{OR}<67.5 ; \mathrm{p}=0.007)$ or IHC $(\mathrm{OR}=5.9 ; 0.85<\mathrm{OR}<52 ; \mathrm{p}=0.05)$ being positive (Table 3 ). All positive ELISA fetuses had positive ELISA cows.

\section{Discussion}

In the present study, from the 41 dairy cows that aborted, $51.2 \%$ were seropositive for $N$. caninum; comparatively lower seropositivity were reported for $N$. caninum in other studies, varying between 6.3 to $28.6 \%$ (MEERSCHMAN et al., 2002; KOIWAI et al., 2005; YILDIZ et al., 2009). In this study, dams that were more than 36 months of age had a higher risk of being seropositive; similar findings were previously described 
Table 1. The outcome of Neospora caninum-induced infections in dairy cows (Bos taurus) and their aborted fetuses.

\begin{tabular}{|c|c|c|c|c|c|c|c|c|c|}
\hline \multirow{2}{*}{$\begin{array}{l}\text { Cow } \\
\text { No }\end{array}$} & \multirow{2}{*}{ Breed } & \multirow{2}{*}{$\begin{array}{l}\text { Age of cattle } \\
\text { (months) }\end{array}$} & \multicolumn{2}{|c|}{ ELISA $^{1}$} & \multirow{2}{*}{$\begin{array}{l}\text { Age of fetus } \\
\text { (months) }\end{array}$} & \multirow{2}{*}{$\begin{array}{c}\text { Fetuses PCR } \\
\begin{array}{c}\text { Pool of } \\
\text { organs }\end{array}\end{array}$} & \multicolumn{2}{|c|}{$\begin{array}{l}\text { Principal histopathological } \\
\text { findings of the brain }\end{array}$} & \multirow{2}{*}{ Fetuses IHC } \\
\hline & & & Cows & $\begin{array}{c}\text { Aborted } \\
\text { fetuses }\end{array}$ & & & $\begin{array}{l}\text { Endothelial } \\
\text { hypertrophy }\end{array}$ & Congestion & \\
\hline 1 & JER & $>48$ & $2.23 / 1.53$ & ND & $\mathrm{Mum}^{2}$ & ND & \multicolumn{2}{|c|}{ ND } & ND \\
\hline 2 & HOL & $>48$ & 0.4 & ND & 7 & - & 0 & - & - \\
\hline 3 & JER & 36 & 0.27 & ND & 8 & ND & ND & ND & ND \\
\hline 4 & $\mathrm{HOL}$ & 33 & $0.12 / 0.09$ & ND & 9 & - & 0 & 0 & - \\
\hline 5 & $\mathrm{HOL}$ & $>48$ & $2.52 / 2.01$ & ND & 5 & + & 0 & +1 & +1 \\
\hline 6 & JER & $>48$ & $0.97 / 1.05$ & ND & 6 & - & 0 & +2 & +2 \\
\hline 7 & $\mathrm{HOL}$ & 24 & $0.0 / 0.07$ & 0.01 & 8 & + & + & $\mathrm{N}$ & - \\
\hline 8 & $\mathrm{HOL}$ & 25 & $0.13 / 0.23$ & 0.01 & 8 & + & + & +1 & +1 \\
\hline 9 & JER & 36 & $0.22 / 0.14$ & 0.0 & 7 & - & ++ & 0 & - \\
\hline 10 & $\mathrm{HOL}$ & $>48$ & $2.07 / 0.18$ & ND & mum & ND & \multicolumn{2}{|c|}{ ND } & ND \\
\hline 11 & JER & 24 & 0.01 & 0.0 & 7 & - & ++ & 0 & - \\
\hline 12 & $\mathrm{HOL}$ & $>48$ & $2.11 / 2.07$ & 0.31 & 8 & + & + & 0 & - \\
\hline 13 & JER & $>48$ & $1.9 / 2.15$ & 3.11 & 7 & - & ++ & +1 & +1 \\
\hline 14 & $\mathrm{HOL}$ & $>48$ & $2.27 / 2.2$ & 0.0 & 7 & + & + & 0 & - \\
\hline 15 & JER & $>48$ & $2.3 / 1.96$ & 1.91 & 7 & + & + & 0 & - \\
\hline 16 & JER & $>48$ & $2.05 / 1.09$ & 0.0 & 6 & - & 0 & +2 & +2 \\
\hline 17 & JER & $>48$ & $0.2 / 0.3$ & 0.0 & 7 & - & + & 0 & - \\
\hline 18 & $\mathrm{HOL}$ & 24 & $0.1 / 0.12$ & 0.0 & 7 & - & 0 & +2 & +2 \\
\hline 19 & JER & $>48$ & $2.01 / 1.95$ & 3.02 & 7 & + & +++ & +2 & +2 \\
\hline 20 & JER & $>48$ & 0.29 & 0.0 & 8 & - & + & 0 & - \\
\hline 21 & JER & 48 & $0.2 / 0.15$ & 0.0 & 9 & - & ++ & 0 & - \\
\hline 22 & JER & $>48$ & 1.92 & ND & 4 & ND & \multicolumn{2}{|c|}{ ND } & ND \\
\hline 23 & JER & $>48$ & $0.36 / 0.19$ & 0.0 & 6 & + & 0 & 0 & - \\
\hline 24 & JER & $>48$ & $1.98 / 1.73$ & ND & 6 & - & 0 & 0 & - \\
\hline 25 & HOL & $>48$ & $1.79 / 2.07$ & ND & 4 & + & 0 & 0 & - \\
\hline 26 & $\mathrm{HOL}$ & 36 & $0.14 / 0.05$ & 0.0 & 6 & - & + & 0 & - \\
\hline 27 & JER & $>48$ & $0.17 / 0.05$ & 0.0 & 6 & - & + & 0 & - \\
\hline 28 & $\mathrm{HOL}$ & $>48$ & $2.6 / 2.33$ & 0.04 & 6 & + & + & 0 & - \\
\hline 29 & $\mathrm{HOL}$ & $>48$ & $2.26 / 2.0$ & 0.51 & 7 & + & + & +2 & +2 \\
\hline 30 & $\mathrm{HOL}$ & 28 & $0.32 / 0.4$ & 0.06 & 8 & - & + & 0 & - \\
\hline 31 & $\mathrm{~J} / \mathrm{H}$ & $>48$ & $0.11 / 0.21$ & 0.06 & 5 & - & 0 & 0 & - \\
\hline 32 & HOL & $>48$ & $1.98 / 1.92$ & 3.08 & 8 & + & + & 0 & - \\
\hline 33 & $\mathrm{HOL}$ & $>48$ & $0.21 / 0.16$ & 0.0 & 7 & - & + & 0 & - \\
\hline 34 & JER & $>48$ & $0.53 / 0.17$ & 1.68 & 7 & + & ++ & +1 & +1 \\
\hline 35 & JER & $>48$ & 1.95 & 2.35 & 6 & - & + & 0 & - \\
\hline 36 & JER & $>48$ & $2.3 / 2.13$ & 0.03 & 7 & - & ++ & 0 & - \\
\hline 37 & JER & $>48$ & $0.16 / 0.18$ & 0.0 & 6 & - & 0 & 0 & - \\
\hline 38 & $\mathrm{HOL}$ & $>48$ & $2.3 / 2.12$ & 1.14 & 8 & + & + & 0 & - \\
\hline 39 & JER & $>48$ & $0.13 / 0.06$ & 0.0 & 7 & - & + & 0 & - \\
\hline 40 & JER & 30 & $0.05 / 0.13$ & 0.0 & 7 & - & ++ & 0 & - \\
\hline 41 & $\mathrm{HOL}$ & $>48$ & $2.07 / 0.18$ & ND & mum & ND & \multicolumn{2}{|c|}{ ND } & ND \\
\hline
\end{tabular}

${ }^{1}$ S/P from ELISA (Idexx) $S / P \geq 0.50$ (positive) and $<0.50$ (negative). ${ }^{2}$ Mummified fetuses (mum) did not have their tissues and blood tested, and age determined. $\mathrm{ND}=$ not done; - (negative); + (positive); JER (Jersey); HOL (Holstein); J/H (Jersey/Holstein); Legend for histopathology: 0, absent; +, discrete; ++, moderate; +++ , severe; IHC = Immunohistochemistry; +1 = positive in the myocardium; $+2=$ positive in the cerebrum.

(DUBEY et al., 2007; HORNOK et al., 2006). It has been demonstrated that sero-prevalence might increase with the age and the number of gestations in beef and dairy cattle (DUBEY et al., 2007; HORNOK et al., 2006), suggesting that horizontal transmission is of importance in cattle herds.
This study demonstrated that $26.7 \%(8 / 30)$ of the serum evaluated fetuses were positives to $N$. caninum antibodies; this results is more elevated, despite the use of different techniques, than that described in a similar study (SANTOS et al., 2005a), that used the IFA and obtained $11.7 \%$ (4/34) of seropositivity. 
Table 2. Association between the age of cows, gestational period, and breed with the presence of antibodies against Neospora caninum from dairy cows that aborted.

\begin{tabular}{|c|c|c|c|c|c|c|}
\hline Variables & Positive (\%) & Negative (\%) & Total & $p$-value ${ }^{1}$ & OR & OR95\% \\
\hline \multicolumn{7}{|c|}{ Age-cows (months) } \\
\hline $24-36$ & $00(0.0)$ & $10(100)$ & $10(24.4)$ & $0.0001^{*}$ & 0.00 & $(0.00,0.31)$ \\
\hline$>36$ & $21(67.7)$ & $10(32.3)$ & $31(75.6)$ & & & \\
\hline Total & $21(51.2)$ & $20(48.8)$ & $41^{2}$ & & & \\
\hline \multicolumn{7}{|c|}{ Trimester of gestation } \\
\hline Second(4-6) & $8(61.5)$ & $5(38.5)$ & $13(34.2)$ & 0.84 & 2.40 & $(0.50,11.9)$ \\
\hline Third (>7) & $10(40.0)$ & $15(60.0)$ & $25(65.8)$ & & & \\
\hline Total & $18(47.4)$ & $20(52.6)$ & $38^{3}$ & & & \\
\hline \multicolumn{7}{|l|}{ Breeds } \\
\hline Jersey & $11(50.0)$ & $11(50.0)$ & $22(55 \%)$ & 0.97 & 0.8 & $(0.19,3.34)$ \\
\hline Holstein & $10(55.5 \%)$ & $8(44.5 \%)$ & $18(45 \%)$ & & & \\
\hline Total & $19(47.5 \%)$ & $21(52.5)$ & $40^{4}$ & & & \\
\hline
\end{tabular}

Table 3. Results of ELISA from dams compared with ELISA, PCR, and IHC from fetuses.

\begin{tabular}{|c|c|c|c|c|c|c|}
\hline Dams & \multirow{2}{*}{\multicolumn{3}{|c|}{$\begin{array}{c}\text { Fetuses } \\
E L I S A\end{array}$}} & p-value & OR & OR95\% \\
\hline & & & & & & \\
\hline & Positives (\%) & Negatives (\%) & $\mathrm{T}(\%)$ & & & \\
\hline+ & $8(61.5)$ & $5(38.5)$ & $13(43.3)$ & $0.0002^{1}$ & $\mathrm{UN}$ & Not accurate \\
\hline - & $0(0)$ & $17(100)$ & $17(56.7)$ & & & \\
\hline $\mathrm{T}(\%)$ & $8(26.7)$ & $\begin{array}{c}22(73.3) \\
P C R\end{array}$ & 30 & & & \\
\hline+ & $11(64.7)$ & $6(35.3)$ & $17(47.2)$ & & & \\
\hline - & $3(15.8)$ & $16(84.2)$ & $19(52.8)$ & $0.007^{2}$ & 9.78 & $(1.63,67.5)$ \\
\hline $\mathrm{T}(\%)$ & $14(38.8)$ & $\begin{array}{c}22(61.2) \\
I H C\end{array}$ & 36 & & & \\
\hline+ & $7(41.2)$ & $10(58.8)$ & $17(47.2)$ & $0.05^{1}$ & 5.9 & $(0.85,52)$ \\
\hline - & $2(10.5)$ & $17(89.5)$ & $19(52.8)$ & & & \\
\hline $\mathrm{T}(\%)$ & $9(25.0)$ & $27(75.0)$ & 36 & & & \\
\hline
\end{tabular}

${ }^{1}$ Fischer exact. ${ }^{2} \mathrm{Chi}$-square by Yates corrected. UN $=$ Undefined.

Additionally, during this study all fetuses that were serum positive originated from dams that were also serum positive for $N$. caninum.

In the present study, there were three cows that had negative serology results for $N$. caninum but the fetuses of 3 were positive by PCR and one of their fetuses tested positive by IHC. Several factors can affect the PCR techniques; sensitivity, specificity, parasite detectability in the presence of host DNA and defective templates, mainly linked to quality of DNA extraction, additionally a false positive result due to contamination at nested-PCR is reported (MÜLLER et al., 2001; MARQUES et al., 2011). Fluctuating of $N$. caninum antibody levels in naturally infected cows was previously described (CARDOSO et al., 2012; CONRAD et al., 1993; DIJKSTRA et al., 2008; KYAW et al., 2005; MARQUES et al., 2011). The observation that some infected dams can exhibit negative antibody values during any gestational period, particularly Neospora at parturition or abortion was previously demonstrated (BENAVIDES et al., 2012; NOGAREDA et al., 2007). It has been reported that 5\% (8/170) (PARÉ et al., 1996) and 3\% (1/33) (MORE et al., 2009) of seronegative cows gave birth to seropositive calves. This shows that caution must be taken in the interpretation of serologic results if they are to be used in control strategies for bovine neosporosis (CONRAD et al., 1993).

It has been demonstrated that abortions caused by $N$. caninum may occur from 3 months of gestation to term (DUBEY \& LINDSAY, 1996). The average $( \pm S D)$ gestational age of abortions that was suggestive for neosporosis in this study was $7.22 \pm 0.66$ months, ranging from 6 to 8 months; similar results have been described (MEERSCHMAN et al., 2002; SAGER et al., 2001).

Although the histopathological alterations seen within the brain are non-specific, positive IHC staining for $N$. caninum was observed either in the cerebrum or in the myocardium of six (60\%) fetuses that also had non-specific histopathological changes. In contrast, typical $N$. caninum-induced lesions were reported within the brain of fetuses that were experimentally infected (BENAVIDES et al., 2012). Additionally, N. caninum-induced necrosis was observed within the skeletal muscles of aborted fetuses whose dams were experimentally infected, but without similar lesions present within the brain, lung, kidneys, and myocardium (McCANN et al., 2007). Nevertheless, these results confirm the 
superiority of IHC relative to histopathology for the identification of $N$. caninum within tissue fragments.

A combination of maternal ELISA and fetal ELISA, PCR and IHC gave a better indication of transmission of the parasite to the fetus than maternal ELISA results alone. The PCR assay is considered as a valuable technique for the diagnosis of $N$. caninum (SERRANO-MARTINEZ et al., 2007), and the results from this study have demonstrated that $38.8 \%$ (14/36) of the aborted fetuses were positive. Similar findings were described by nested PCR where $80 \%$ and $57.7 \%$ (MEDINA et al., 2006; YAO et al., 2009) of aborted fetuses were positive for $N$. caninum, in Mexico and China, respectively. However, other studies (PEREIRA-BUENO et al., 2003; RAZMI et al., 2006, 2010; SAGER et al., 2001) have described values that ranged from 11.9 to $33 \%$. Thus, the results of this investigation are in agreement with the diagnosis of $N$. caninum-associated abortions in dairy cattle worldwide, where it was demonstrated that 12 to $45 \%$ of aborted fetuses are infected by this protozoan parasite (DUBEY, 2005).

In summary, the present study observed a high frequency of $N$. caninum in abortions from dairy cows from southern Brazil, with a higher $N$. caninum prevalence found in cows that were older than 36 months. In addition, serology, PCR, and IHC should be used in combination for better diagnosis of neosporosis in cattle.

\section{Acknowledgements}

The authors would like to thank Coordenaçáo de Aperfeicoamento de Pessoal de Nivel Superior (CAPES AUXPE-1345/11), and Conselho Nacional de Desenvolvimento Cientifico e Tecnologico (CNPq 304083/2015-1). JL Garcia and S. A. Headley are recipient of CNPq fellowships. EA Innes, F Katzer and F. Chianini were supported by the Scottish Government, and The Rural and Environment Science and Analytical Services.

\section{References}

Anderson ML, Andrianarivo AG, Conrad PA. Neosporosis in cattle. Anim Reprod Sci 2000; 60-61: 417-431. PMid:10844212. http://dx.doi. org/10.1016/S0378-4320(00)00117-2.

Benavides J, Katzer F, Maley SW, Bartley PM, Canton G, PalareaAlbaladejo J, et al. High rate of transplacental infection and transmission of Neospora caninum following experimental challenge of cattle at day 210 of gestation. Vet Res 2012; 43(1): 83. PMid:23228067. http://dx.doi. org/10.1186/1297-9716-43-83.

Bildfell R, Davidson J, Dubey JP. Neospora-induced protozoal bovine abortion in Prince Edward Island. Can Vet J 1994; 35(2): 122. PMid:8069823.

Cabral AD, Camargo CN, Galleti NT, Okuda LH, Pituco EM, Fava CD. Diagnosis of Neospora caninum in bovine fetuses by histology, immunohistochemistry, and nested-PCR. Rev Bras Parasitol Vet 2009; 18(4): 14-19. PMid:20040203. http://dx.doi.org/10.4322/rbpv.01804003.

Cardoso JM, Amaku M, Araújo AJ, Gennari SM. A longitudinal study of Neospora caninum infection on three dairy farms in Brazil. Vet Parasitol 2012; 187(3-4): 553-557. PMid:22309800. http://dx.doi.org/10.1016/j. vetpar.2012.01.019.
Collantes-Fernández E, Arnáiz-Seco I, Burgos BM, Rodríguez-Bertos A, Aduriz G, Fernández-García A, et al. Comparison of Neospora caninum distribution, parasite loads and lesions between epidemic and endemic bovine abortion cases. Vet Parasitol 2006; 142(1-2): 187-191. PMid:16884852. http://dx.doi.org/10.1016/j.vetpar.2006.05.030.

Conrad PA, Sverlow K, Anderson M, Rowe J, BonDurant R, Tuter $\mathrm{G}$, et al. Detection of serum antibody responses in cattle with natural or experimental Neospora infections. J Vet Diagn Invest 1993; 5(4): $572-$ 578. PMid:8286457. http://dx.doi.org/10.1177/104063879300500412.

Corbellini LG, Driemeier D, Cruz CF, Gondim LF, Wald V. Neosporosis as a cause of abortion in dairy cattle in Rio Grande do Sul, southern Brazil. Vet Parasitol 2002; 103(3): 195-202. PMid:11750112. http:// dx.doi.org/10.1016/S0304-4017(01)00600-8.

Corbellini LG, Pescador CA, Frantz F, Wunder E, Steffen D, Smith $\mathrm{DR}$, et al. Diagnostic survey of bovine abortion with special reference to Neospora caninum infection: importance, repeated abortion and concurrent infection in aborted fetuses in Southern Brazil. Vet J2006; 172(1): 114120. PMid:16772136. http://dx.doi.org/10.1016/j.tvjl.2005.03.006.

Dijkstra T, Lam TJ, Bartels CJ, Eysker M, Wouda W. Natural postnatal Neospora caninum infection in cattle can persist and lead to endogenous transplacental infection. Vet Parasitol 2008; 152(3-4): 220-225. PMid:18280662. http://dx.doi.org/10.1016/j.vetpar.2007.12.034.

Dubey JP, Jenkins MC, Rajendran C, Miska K, Ferreira LR, Martins J, et al. Gray wolf (Canis lupus) is a natural definitive host for Neospora caninum. Vet Parasitol2011; 181(2-4): 382-387. PMid:21640485. http:// dx.doi.org/10.1016/j.vetpar.2011.05.018.

Dubey JP, Lindsay DS. A review of Neospora caninum and neosporosis. Vet Parasitol 1996; 67(1-2): 1-59. PMid:9011014. http://dx.doi.org/10.1016/ S0304-4017(96)01035-7.

Dubey JP, Schares G, Ortega-Mora LM. Epidemiology and control of neosporosis and Neospora caninum. Clin Microbiol Rev 2007; 20(2): 323-367. PMid:17428888. http://dx.doi.org/10.1128/CMR.00031-06.

Dubey JP. Neosporosis in cattle. Vet Clin North Am Food Anim Pract 2005; 21(2): 473-483. PMid:15955441. http://dx.doi.org/10.1016/j. cvfa.2005.03.004.

Dubey JP. Review of Neospora caninum and neosporosis in animals. Korean J Parasitol 2003; 41(1): 1-16. PMid:12666725. http://dx.doi. org/10.3347/kjp.2003.41.1.1.

Gondim LF, McAllister MM, Pitt WC, Zemlicka DE. Coyotes (Canis latrans) are definitive hosts of Neospora caninum. Int J Parasitol 2004; 34(2): 159-161. PMid:15037103. http://dx.doi.org/10.1016/j.ijpara.2004.01.001.

Haddad JP, Dohoo IR, Van Leewen JA. A review of Neospora caninum in dairy and beef cattle--a Canadian perspective. Can Vet J 2005; 46(3): 230-243. PMid:15884645.

Hall CA, Reichel MP, Ellis JT. Neospora abortions in dairy cattle: diagnosis, mode of transmission and control. Vet Parasitol 2005; 128(3-4): 231241. PMid:15740860. http://dx.doi.org/10.1016/j.vetpar.2004.12.012.

Hornok S, Edelhofer R, Hajtos I. Seroprevalence of neosporosis in beef and dairy cattle breeds in Northeast Hungary. Acta Vet Hung 2006; 54(4): 485-491. PMid:17278720. http://dx.doi.org/10.1556/AVet.54.2006.4.6.

King JS, Slapeta J, Jenkins DJ, Al-Qassab SE, Ellis JT, Windsor PA. Australian dingoes are definitive hosts of Neospora caninum. Int J Parasitol 2010; 40(8): 945-950. PMid:20149793. http://dx.doi.org/10.1016/j. ijpara.2010.01.008. 
Koiwai M, Hamaoka T, Haritani M, Shimizu S, Kimura K, Yamane I. Proportion of abortions due to neosporosis among dairy cattle in Japan. JVet Med Sci 2005; 67(11): 1173-1175. PMid:16327231. http://dx.doi. org/10.1292/jvms.67.1173.

Kyaw T, Suwimonteerabutr J, Virakul P, Lohachit C, Kalpravidh W. Seronegative conversion in four Neospora caninum-infected cows, with a low rate of transplacental transmission. Vet Parasitol 2005; 131(1-2): 145150. PMid:15939537. http://dx.doi.org/10.1016/j.vetpar.2005.04.025.

Maley SW, Buxton D, Rae AG, Wright SE, Schock A, Bartley PM, et al. The pathogenesis of neosporosis in pregnant cattle: inoculation at midgestation. J Comp Pathol 2003; 129(2-3): 186-195. PMid:12921725. http://dx.doi.org/10.1016/S0021-9975(03)00032-X.

Marques FA, Headley AS, Figueredo-Pereira V, Taroda A, Barros LD, Cunha IA, et al. Neospora caninum: evaluation of vertical transmission in slaughtered beef cows (Bos indicus). Parasitol Res 2011; 108(4): 10151019. PMid:21063729. http://dx.doi.org/10.1007/s00436-010-2146-x.

McAllister MM, Dubey JP, Lindsay DS, Jolley WR, Wills RA, McGuire AM. Dogs are definitive hosts of Neospora caninum. Int J Parasitol 1998; 28(9): 1473-1478. PMid:9770635. http://dx.doi.org/10.1016/S00207519(98)00138-6.

McCann CM, McAllister MM, Gondim LF, Smith RF, Cripps PJ, Kipar A, et al. Neospora caninum in cattle: experimental infection with oocysts can result in exogenous transplacental infection, but not endogenous transplacental infection in the subsequent pregnancy. Int J Parasitol 2007; 37(14): 1631-1639. PMid:17624353. http://dx.doi.org/10.1016/j. ijpara.2007.05.012

Medina L, Cruz-Vázquez C, Quezada T, Morales E, García-Vázquez Z. Survey of Neospora caninum infection by nested PCR in aborted fetuses from dairy farms in Aguascalientes, Mexico. Vet Parasitol 2006; 136(3-4): 187-191. PMid:16332413. http://dx.doi.org/10.1016/j.vetpar.2005.11.003.

Meerschman F, Speybroeck N, Berkvens D, Rettigner C, Focant C, Leclipteux T, et al. Fetal infection with Neospora caninum in dairy and beef cattle in Belgium. Theriogenology 2002; 58(5): 933-945. PMid:12212893. http://dx.doi.org/10.1016/S0093-691X(02)00934-2.

Moré G, Bacigalupe D, Basso W, Rambeaud M, Beltrame F, Ramirez B, et al. Frequency of horizontal and vertical transmission for Sarcocystis cruzi and Neospora caninum in dairy cattle. Vet Parasitol 2009; 160(1-2): 51-54. PMid:19070964. http://dx.doi.org/10.1016/j.vetpar.2008.10.081.

Müller N, Sager H, Hemphill A, Mehlhorn H, Heydorn AO, Gottstein B. Comparative molecular investigation of Nc5-PCR amplicons from Neospora caninum NC-1 and Hammondia heydorni-Berlin-1996. Parasitol Res 2001; 87(10): 883-885. PMid:11688897. http://dx.doi.org/10.1007/ s004360100463.

Nogareda C, López-Gatius F, Santolaria P, García-Ispierto I, Bech-Sàbat G, Pabón M, et al. Dynamics of anti-Neospora caninum antibodies during gestation in chronically infected dairy cows. Vet Parasitol 2007; 148(3-4): 193-199. PMid:17643822. http://dx.doi.org/10.1016/j.vetpar.2007.06.032.

Orlando DR, Costa RC, Soares BA, Oliveira NSC, Nascimento LC, Peconick AP, et al. Neospora caninum abortions in cattle in southern Minas Gerais, Brazil. Pesq Vet Bras 2013; 33(11): 1332-1338. http:// dx.doi.org/10.1590/S0100-736X2013001100008.

Paré J, Thurmond MC, Hietala SK. Congenital Neospora caninum infection in dairy cattle and associated calfhood mortality. Can J Vet Res 1996; 60(2): 133-139. PMid:8785719.

Pereira-Bueno J, Quintanilla-Gozalo A, Pérez-Pérez V, Espi-Felgueroso A, Alvarez-Garcĺa G, Collantes-Fernández E, et al. Evaluation by different diagnostic techniques of bovine abortion associated with Neospora caninum in Spain. Vet Parasitol2003; 111(2-3): 143-152. PMid:12531290. http:// dx.doi.org/10.1016/S0304-4017(02)00361-8.

Pescador CA, Corbellini LG, Oliveira EC, Raymundo DL, Driemeier D. Histopathological and immunohistochemical aspects of Neospora caninum diagnosis in bovine aborted fetuses. Vet Parasitol 2007; 150(1-2): 159163. PMid:17904290. http://dx.doi.org/10.1016/j.vetpar.2007.08.028.

Razmi GR, Mohammadi GR, Garrosi T, Farzaneh N, Fallah AH, Maleki M. Seroepidemiology of Neospora caninum infection in dairy cattle herds in Mashhad area, Iran. Vet Parasitol 2006; 135(2): 187-189. PMid:16289861. http://dx.doi.org/10.1016/j.vetpar.2005.09.004

Razmi GR, Zarea H, Naseri Z. A survey of Neospora caninum-associated bovine abortion in large dairy farms of Mashhad, Iran. Parasitol Res 2010; 106(6): 1419-1423. PMid:20352453. http://dx.doi.org/10.1007/ s00436-010-1820-3.

Sager H, Fischer I, Furrer K, Strasser M, Waldvogel A, Boerlin P, et al. A Swiss case-control study to assess Neospora caninum-associated bovine abortions by PCR, histopathology and serology. Vet Parasitol 2001; 102(1-2): 1-15. PMid:11705647. http://dx.doi.org/10.1016/S03044017(01)00524-6.

Santos APME, Navarro IT, Bracarense APFRL, Freire RL, Marana ERM, Ogawa L, et al. Dairy cow abortion associated with Neospora caninum and other infectious agents. Arq Bras Med Vet Zootec 2005a; 57(4): 545-547. http://dx.doi.org/10.1590/S0102-09352005000400017.

Santos APME, Navarro IT, Freire RL, Vidotto O, Bracarense APFRL. Neospora caninum in dairy cattle in Paraná State, Brazil: histological and immunohistochemical analysis in fetuses. Semina: Cienc Agrar 2005b; 26(4): 559-562. http://dx.doi.org/10.5433/1679-0359.2005v26n4p559.

Serrano-Martínez E, Ferre I, Osoro K, Aduriz G, Mota RA, Martinez A, et al. Intrauterine Neospora caninum inoculation of heifers and cows using contaminated semen with different numbers of tachyzoites Theriogenology 2007; 67(4): 729-737. PMid:17126895. http://dx.doi. org/10.1016/j.theriogenology.2006.10.004.

Von Blumroder D, Schares G, Norton R, Williams DJ, Esteban-Redondo I, Wright $S$, et al. Comparison and standardisation of serological methods for the diagnosis of Neospora caninum infection in bovines. Vet Parasitol 2004; 120(1-2): 11-22. PMid:15019139. http://dx.doi.org/10.1016/j. vetpar.2003.12.010.

Wouda W, Dubey JP, Jenkins MC. Serological diagnosis of bovine fetal neosporosis. J Parasitol 1997; 83(3): 545-547. PMid:9194848. http:// dx.doi.org/10.2307/3284431.

Wouda W. Diagnosis and epidemiology of bovine neosporosis: a review. Vet Q 2000; 22(2): 71-74. PMid:10789513. http://dx.doi.org/10.1080 /01652176.2000.9695028.

Yao L, Yang N, Liu Q, Wang M, Zhang W, Qian WF, et al. Detection of Neospora caninum in aborted bovine fetuses and dam blood samples by nested PCR and ELISA and seroprevalence in Beijing and Tianjin, China. Parasitology 2009; 136(11): 1251-1256. PMid:19660160. http:// dx.doi.org/10.1017/S0031182009990813.

Yildiz K, Kul O, Babur C, Kilic S, Gazyagci AN, Celebi B, et al. Seroprevalence of Neospora caninum in dairy cattle ranches with high abortion rate: special emphasis to serologic co-existence with Toxoplasma gondii, Brucella abortus and Listeria monocytogenes. Vet Parasitol 2009; 164(2-4): 306-310. PMid:19592171. http://dx.doi.org/10.1016/j. vetpar.2009.06.004. 